\title{
The Influence of Pintrich's Self-regulated Learning Model on Elementary Teacher Candidates in a Life Science Course
}

\author{
Barış Çetin \\ Correspondence: Barış Çetin, Canakkale 18 Mart University, Faculty of Education, Turkey. \\ Received: June 4, 2017 \\ Accepted: June 21, 2017 Online Published: July 3, 2017 \\ doi:10.11114/jets.v5i8.2460 \\ URL: https://doi.org/10.11114/jets.v5i8.2460
}

\begin{abstract}
The purpose of this research was to determine whether the use of activities based on Pintrich's self-regulated learning model effect the self-regulated learning perceptions of elementary teacher candidates within a Life Science course. The research was organized in accordance with the quasi-experimental designs model. This study was conducted within a classroom consisting of 5 male and 34 female (aged 20 to 25) elementary teacher candidates at Canakkale 18 Mart University, Education Faculty, and Department of Basic Education. Data was collected utilizing the "Self-regulated Learning Perception Scale" and the "Personal Information Form". As a result of the research, the use of Pintrich's self-regulated learning based activities has been found to improve the self-regulated learning perceptions of the elementary teacher candidates.
\end{abstract}

Keywords: the faculty of education, elementary teacher candidate, self-regulated learning, the life science course

\section{Introduction}

Life Science courses prepare students for life and provide applicable vital information. It is expected that future classroom teachers who are likely to teach Life Science courses will themselves, have a high level of personal self-regulated learning skills once they have completed their undergraduate education. As such, self- regulated learning skills are an important concept to understand for elementary teacher candidates and a course on how to teach Life Science content to children is typically a requirement for elementary school teacher candidates in Turkey. The self-regulated learning model provides an opportunity for pre-service teacher candidates to develop their understanding of the concept through evaluating their current applicable knowledge and skills in Life Science related content. This study investigated whether instructional activities based on Pintrich's self-regulated learning model implemented in a university course focused on the teaching of primary and secondary Life Science material affected the perceived levels of self efficacy related to self-regulated learning knowledge and skills in participating university students enrolled in the course.

\subsection{Self-regulated Learning}

Self-regulated learning (SRL) is a process, which is proactive, and in this process, individuals are expected to organize and manage their thoughts, emotions, behaviours, and their environment to fulfil their academic objectives (Ramdass \& Zimmerman, 2011). Moreover, SRL is an active, constructive process in which learners set their goals regarding their learning and they then strive to monitor, regulate, and control their cognition, motivation, and behaviour, in accordance with their goals and the contextual features of the environment (Pintrich, 2000, p.453). SRL promotes learners' self-competence and may also explain students' connection to motivation and achievement (Zimmerman, 1989). SRL processes do not just enrich motivation, but also predict academic success and athletic involvement (Zimmerman \& Kitsantas, 2005). Self-regulated learning involves developing knowledge, skills, and attitudes which can be transferred from one learning context to another and from learning situations in which this information has been acquired to a leisure and work related context (Boekaerts, 1999, p.446).

The most widely known models in the literature can be listed as; Zimmerman's Social Cognitive Model of Self-regulation (1990, 1998), Boekaerts' Model of Adaptable Learning (1992), Winne's Four-stage Model of Self-regulated Learning (Winne, 1996; Winne \& Hadwin, 1998); Borkowski's Process-oriented Model of Metacognition (1996) and Pintrich's General Framework for SRL (2000). In this study, Pintrich's General Framework for SRL (2000) was utilized as the main framework. Pintrich's General Framework for SRL includes cognitive, motivational, sensory, and biological individual processes. Pintrich's self-regulated model has four stages: 1) forethought, planning, and 
activation, 2) monitoring, 3) control, and 4) reaction and reflection (Pintrich, 2000):

Forethought, planning, and activation: This phase includes identifying goals, accepting and directing the determined goals, planning time and space, determining the perceptions about the tasks, and determining the motivational effects.

Monitoring: At this stage, an individual understands his/her own cognitive awareness, which includes awareness of the effects of one's own motivation, one's consciousness of the council, an awareness of one's time and the need for help, as well as the awareness of the task and the task related

Control: At this stage, an individual has chosen and implemented appropriate learning strategies for thinking; it is the moment when the motivational strategies are selected and applied. Self-observed behaviours are exhibited along with an increase and decrease in effort while one re-evaluates these procedures and/or makes changes in the assigned mission.

Reaction and reflection: This is the stage when individuals make cognitive judgments and evaluations regarding; showing effective reaction, insistence, giving up, choice making, and evaluating content. It is the time when s/he evaluates her/his task. In short, it is the time that the individual assesses himself/herself about whether there is a difference between the target and the performance he/she has demonstrated in the beginning.

\subsection{Self-regulated Learning and the Life Science Teaching Course}

The Life Science Course taken by most elementary school children in Turkey undertakes the function of preparing children to investigate one's self to make them aware of their life by selecting and organizing the most basic knowledge skills, attitudes, thoughts, and values appropriate to their age. Life science is the first course that educates children on such topics as how to be a 'good person' and a 'good citizen' through the educational process. This course facilitates the acquisition of behaviours in students that are necessary for effective adaptation to their environment (Akınoğlu, 2004). Sönmez (2005) defines the course of Life Science as one intended to impart to children, a process of establishing a natural and social reality based on evidence, and help them acquire knowledge at the end of this process.

Life Science course content is comprised of social science and art curriculum as well as curriculum focused on contemporary ideas and values (Sönmez, 2005). The purpose of the Life Science course is to prepare elementary school students for life by considering the psycho-social characteristics of children; (Özdemir, 1998), by introducing the weak and strong sides of the child as a person who has a peaceful, creative and autonomous life and who enjoys democratic attitudes (Güngördü, 2001). The Life Science lessons help children satisfy their curiosity about the social and natural phenomena that are happening around them. It helps children to recognise their surroundings and adapt to them easily. This course prepares a favourable environment for citizenship education.

The New Life Science Curriculum includes many achievements and topics that will help students identify him/herself, one's feelings, thoughts, values, and strengths (Kabapınar, 2007). Life Science offers 72 self-management skills in new life science curriculum at the 1 st grade; there are 43 self-management skills in grade two; there are 39 objectives of self-innovation skills in the 3rd grade (Kılıç, 2015, Milli Eğitim Bakanlığ1, 2009). In the life science curriculum, there are benefits that will enable students to acquire self-management skills. This result shows that the New Life Science Teaching Curriculum aims to improve children's self-management skills. It is expected that the elementary teacher candidates who will be the teachers of this curriculum will also consist of high achievers within the self-regulated learning skills content. Elementary teacher candidates are expected to be at the top levels of self-learning strategies so that they can adapt to their needs and adapt to teaching needs of children once they have completed their undergraduate education. In this respect, it is important to use teaching activities in accordance with the self-regulated learning model in the teaching of life science teaching lessons.

Self-regulated learning is also an approach to learning that individuals can use not only in the school but also in life. The role of the teacher grows in the implementation of this learning approach (Sarı \& Akınoğlu, 2009). In Turkey, since the 2005-2006 school year, students have been receiving an education based on the supervisor approach and have a student-centered understanding. The configurator is critically sceptical, questioning the active, self-learning responsibility of this approach. The implementation of the constructivist approach requires that teachers have a high level of self-organizing skill. The currently used primary school Life Science curriculum requires children to acquire the skills of self-re-organization. It is important to know the level of self- regulated learning skills of classroom teacher candidates and to determine the effectiveness of Pintrich's self-regulated learning model in supporting the learning of these skills.

A review of the current literature showed a relationship between self-regulated learning and academic achievement (Zimmerman \& Martinez-Pons, 1990; Butler \& Winne, 1995; Mega, Ronconi \& De Beni, 2014; Heikkilä \& Lonka, 2006; Zimmerman, Bandura \& Martinez-Pons, 1992). Additionally, some researchers have examined if any predictive relationships exist between self-regulated learning aptitudes and GPA (Ekhlas \& Shangarffam, 2013; Kim \& Seo, 2013; Kosnin, 2007). 
Self-regulated learning skills can be taught to students if the necessary learning environments are provided. Among the primary objectives of schools should be to provide pupils with the ability to organize. The ability to use self-regulated learning is not only important in the life of teachers but also in any typical life process (Eker, 2014) Teachers know how to improve their self-regulated strategies when they learn what they need to do during their undergraduate and graduate education and they can then develop advanced learners.

Kimber (2009) found that preservice elementary teachers' mathematical achievements did not increase the use of self-regulated learning strategies. Quince (2013) found that community college students' final general education course grades and self-regulated learning skills were not statistically significant. In Eker and Arsal (2014), in the 7th grade Social Science classes, they found that the learning activities of the students based on learning logs were effective in promoting the self-regulating strategies of the students. No research was found that focused specifically on the use of Pintrich's self-regulated learning model domestically and externally has influenced the level of learning of the Life Science Teaching Course in the classrooms of Elementary Teacher Candidates. This research partially fills this gap in the literature. The purpose of this research is to determine whether the use of Pintrich's Self-Regulated Learning model based learning activities in classroom instruction affected self-regulated learning perceptions of classroom teacher candidates.

\section{Methods}

Quasi-experimental designs, as one type of experimental design, use a pre- and post-test design approach. It includes assignment of groups to the sample but does not employ random assignment by which students are randomly assigned to such groups (Creswell, 2012). The assigned single groups and individuals are measured or observed concerning a dependent variable both before and following the exposure to a treatment (Fraenkel \& Wallen, 2008). In this research, a quasi-experimental design was used as the experimental method.

\subsection{Participants}

The participants of this research were composed of 34 female and 5 male (aged 20 to 25) teacher candidates who were studying at Canakkale 18 Mart University, Faculty of Education, and Department of Basic Education. The sampling utilized in this study is purposeful sampling. Fraenkel \& Wallen (2008) contend that within such design, investigators use their personal judgment in choosing the sample based on knowledge previously obtained from the population and in parallel with the purpose of the research. Researchers of the study assume they are free to use their knowledge obtained from the population to judge if a particular sample will be a good representative of the target sample.

\subsection{Instruments}

The Self-regulated Learning Perception Scale (Turan, 2009) consists of 41 items in four dimensions: motivation and action to learning (7 items), planning and setting a goal (8 items), strategies for learning and assessment (9 items), and lack of self-directedness ( 7 items). The items in the questionnaire utilized a five-point Likert scale and each choice was assigned a value between one and five. The item scores were then summed to have sub-dimensions and total scores for each participant in the study. When the total score is considered, the minimum score is 41 and the maximum score is 205. Cronbach's alpha values of the subscales were found to be $0.88,0.91,0.83$, and 0.76 , respectively (Turan, Demirel \& Sayek, 2009).

\subsection{Implementation Process}

The data were collected through the "Self-Regulated Learning Perception Scale" and the "Personal Information Form" in a face-to-face format with the participants who volunteered to participate in the study and enrolled in the Life Science Teaching Class at the Department of Elementary Education at the Faculty of Education at COMU during the winter and spring semesters of the 2016-2017 academic year.

The implementation of the independent variable in this research is based on Paul Pintrich's self-learning model. The application steps of the model are Forethout, planning, and activation: The objectives of the field experience in primary school life science courses and elementary school were determined. It was stated that it is necessary to finish the field experience activities in the primary school life science courses and the elementary school in a certain period of time. It was revealed for the class teacher candidate that students' behaviour should be monitored and planned as these two activities were carried out. The positive perceptions of the elementary school life science lesson and the field experience to be made in elementary school are positive; there are two activities that can be carried out by class teacher candidates

Monitoring: Class teacher candidates' field experiences and performances were monitored. In the lecture of life science teaching lesson, they followed the primary life science course and watched their performances. They saw the motivation in their field experiences and elementary school life science lessons in primary school. Primary School Life Science Surveys have the ability to monitor whether their own efforts in narration are sufficient or not. During the implementtaions at schools, you see whether you need further help or not. When these two activities take place, they 
understand the differences in the classroom environment of the Life Science course in primary school and the classroom environment of primary school Life Science course in the Faculty of Education.

Control: Elementary teacher candidates learn to choose and apply appropriate learning strategies while teaching a primary school life science course. Elementary teacher candidates are expected to use evidence based strategies to motivate other elementary teacher candidate classmates as they devise and provide practice elementary age focused life science lessons to their classmates. Lessons are also devised and provided to real elementary age children as part of a required field experience within the related teacher preparation course. Elementary teacher candidates improve their performance through the utilization of feedback given to them by their professors, their classmates and practicing teachers in the field. Feedback focuses on any deficiencies in utilized strategies, methods and techniques regarding their practice lessons.

Reaction and reflection: Following the course, teacher candidates are evaluated as to the efficacy in providing Life Science curriculum to children. Additionally, teacher candidates enrolled in the course self reflect on their abilities and performance drawing from feedback provided by their classmates and practicing teachers that observed their efforts in the field portion of the course. A poor evaluation results in a candidate returning to their field experience school so that he/she can achieve a better performance level. Those that have achieved a satisfactory performance are marked accordingly and move on within the teacher education program.

After evaluating the teacher candidates' primary school Life Science course experiences at schools in the Faculty of Education, they evaluated themselves. Those who believed that the performance of elementary teacher candidates was low in the direction of feedback from other elementary school teacher candidates in the classroom and the feedback was given by the elementary teacher candidates, understood that they needed to do additional work to make up for their deficiencies. They were aware that elementary teacher candidates who were aware of their poor performance in the field experience in primary school should go for the same primary school field experience. The elementary school teacher candidates understand that the field experience is a useful activity for them, and no further experience at a different elementary school is needed in their field.

\subsection{Data Analysis}

In this research, a paired sample t-test analysis technique was used to determine whether the teaching activities used as a basis for Pintrich's self-regulated model in the course of Life Science Teaching were effective. Ho (2014, p.63) paired-samples t-test was used in the analysis regarding the repeated measures or correlated groups design, in which each subject is tested twice on the same variable. This type requires a before and after design.

\section{Results}

In this section, Sample is used as a result of pair samples t-test analysis to determine whether the use of educational activities based on Pintrich's formal learning model is effective for elementary teacher candidates. Results are detailed in Table 1.

Table1. T-test results between the pretest and posttest self-regulated learning perception scores of the classroom teacher candidates

\begin{tabular}{|c|c|c|c|c|c|c|}
\hline & $\mathrm{N}$ & M & Std.Deviation & SD & $\mathrm{t}$ & $\mathrm{p}$ \\
\hline Pretest -SRL total scores & 39 & 3.6573 & .32255 & & & \\
\hline Postest - SRL total scores & 39 & 3.8255 & .22532 & 38 & -4.042 & .000 \\
\hline Motivation and action to learning (Pretest) & 39 & 4.0476 & .44255 & & -.291 & .773 \\
\hline Motivation and action to learning (Posttest) & 39 & 4.0659 & .31409 & 38 & & \\
\hline Planning and goal setting (Pretest Ontest) & 39 & 4.0705 & .43566 & 38 & -.167 & \\
\hline Planning and goal setting (Postest) & 39 & 4.0801 & .28889 & & & .868 \\
\hline $\begin{array}{l}\text { Strategies for learning and assessment } \\
\text { (Pretest) }\end{array}$ & 39 & 3.8853 & .42379 & & & \\
\hline $\begin{array}{l}\text { Strategies for learning and assessment } \\
\text { (Postest) }\end{array}$ & 39 & 3.8812 & .26391 & 38 & .070 & .944 \\
\hline Lack of self-directedness (Pretest) & 39 & 3.2930 & .72470 & 38 & 2.117 & .041 \\
\hline Lack of self-directedness (Postest) & 39 & 3.0403 & 63799 & & & \\
\hline
\end{tabular}

According to Table 1, there is a statistically significant difference in the level of self-regulated learning perception total scores of classroom teacher candidates $(\mathrm{t}(38)=-4.042, \mathrm{p}=.000<.01)$. The comparison between pre-test and post-test scores of motivation and action to learning $(\mathrm{t}(38)=-291, \mathrm{p}=.773>.05)$; of planning and goal setting $(\mathrm{t}(38)=-.167, \mathrm{p}$ $=.868>.05)$; and strategies for learning and assessment $(\mathrm{t}(38)=.070, \mathrm{p}=.944>.05)$ did not yield statistically 
significant results. A statistically significant difference was found in favor of pretest in sub-factor of "Lack of self-directedness" $(\mathrm{t}(38)=2.117, \mathrm{p}=.000<.05)$ ". In the sub-focusses of "motivation and action to learning" and "planning and goal setting", the posttest leg of the arrhythmic subjects seems to be high

\section{Conclusions and Discussion}

In this study, teacher candidates' self-regulated learning perceptions were examined to understand any differences between a group that utilized Pintrich's Self-Regulated Learning model based learning activities in the Life Science Teaching class and a group that did not use such in the class. It was found that educational activities related to Pintrich's model experienced by teacher candidates had a positive effect on their SRL scores as measured by the Self-regulated Learning Perception Scale (Turan, 2009) over those that did not experience such activities. This is illustrated by the significant increase of self-regulated learning perception scores in total and in one sub-factor; lack self-directedness. Other sub-factors did not produce statistically significant results.

There are similar research results supporting this finding. For example, Kuyumcu Vardar (2011) found that the use of self-regulation strategies increased the level of English proficiency of university students. Hu (2007) found that community college students who received the SRL strategies training scored significantly higher in achievement than those who did not receive the training. The findings of this research show similarities with the results of the research given above. The use of educational activities based on Pintrich's self-regulated learning model in the Life Science Teaching course-related education has increased the self-organizing learning perceptions of the future classroom teachers. In other words, it can be concluded that Pintrich's educational activities based on the self-regulated learning model increase the classroom teacher candidates' peceptions regarding self-regulated learning efficacy. When the sub-factors were considered "Motivation and action to learning", "planning and goal setting", "strategies for learning and assessment," there was no statistically significant difference between the pre and post-test scores of the sub-factors. In this study, only the sub-factor of "lack of self-directedness" showed a significant difference in the pre-test. The reason for the dependency subfactor being introduced into the pretest is that the candidate class teachers do not have enough trainings and education in their elementary, middle school and high school educations as part of constructivist learning approach

However, the results obtained from these findings suggest that teacher-centered thinking continues to exist in classroom teacher candidates. As for the reasons one might consider that classroom teacher candidates may be considering personal scores on marked items (GPA) more so than considering personal analysis of learning regarding any given topic. Teacher candidates may be continuing to think more about questions on exams rather than concentrating on a sense of 'learning to learn'. Teacher candidates may prefer to acquire concrete knowledge and may not wish to concentrate on actively engaging in their learning environment in accordance with the logic of the constructivist mentality. If this is the case for teacher candidates, considerations remain as to if such candidates can make the change from a teacher-centered approach to education to a student/learner-centered approach. It may be for this reason that the candidates who were taught using the SRL strategies coniciced with the increased "factor of learning" sub-factor scores.

\section{Recommendation}

Post-secondary instructors who have a role in educating elementary school teacher candidates should include learning activities that promote self-regulated learning skills for elementary teacher candidates in their lessons. Further qualitative research on the effectiveness of self-regulatory learning skills should also be conducted in the course of Life Science Teaching in order to better understand the differences in teacher candidate perceptions. The duration of the Field experience should also be increased thus giving teacher candidates more practice in utilizing SRL strategies in their lesson methodologies.

\section{References}

Akınoğlu, O. (2004). Hayat bilgisi ve sosyal bilgiler ögrretimi. Öztürk, C. ve Dilek D. (Editorler). (ss.2-15). Ankara: Pegem Akademi Yayıncılık.

Boekaerts, M. (1992). The adaptable learning process: initiating and maintaining behavioural change. Applied Psychology: An International Review, 41, 377-397. https://doi.org/10.1111/j.1464-0597.1992.tb00713.x

Boekaerts, M. (1999). Self-regulated learning: where we are today. International Journal of Educational Research, 31, 445-457. https://doi.org/10.1016/S0883-0355(99)00014-2

Borkowski, J. G. (1996). Metacognition: theory or chapter heading? Learning and Individual Differences, 8, 391-402. https://doi.org/10.1016/S1041-6080(96)90025-4

Butler, D. L., \& Winne, P. H. (1995). Feedback and self-regulated learning: A theoretical synthesis. Review of Educational Research, 65, 245-281. https://doi.org/10.3102/00346543065003245 
Creswell, J. W. (2012). Educational research Planning, conducting, and evaluating quantitative and qualitative research (4th. ed.). New Jersey: Pearson Merrill Prentice Hall.

Eker, C. (2014). A comparative approach to self-regulated learning models. Turkish Studies - International Periodical For The Languages, Literature and History of Turkish, 9(8), 417-433.

Eker, C., \& Arsal, Z. (2014). The impact of Teaching Diaries on the Use of Students' Self-Regulation Strategies. Karaelmas Journal of Educational Sciences, 2, 80-93.

Ekhlas, N. N., \& Shangarffam, N. (2013). The relationship between determinant factors of self-regulation strategies and main language skills and overall proficiency. Procedia-Social and Behavioural Sciences, 70, 137-147. https://doi.org/10.1016/j.sbspro.2013.01.049

Fraenkel, J. R., \& Wallen, N. E. (2008). How to design and evaluate research in education (7 th ed.). New York, NY: Mc Graw Hill Higher Education.

Güngördü, E. (2001). Illköğretimde hayat bilgisi ve sosyal bilgiler öğretimi. Ankara: Nobel Yayın Dağıtım.

Heikkilä, A., \& Lonka, K. (2006). Studying in higher education: students' approaches to learning, self-regulation, and cognitive strategies. Studies in Higher Education, 31(1), 99-117. https://doi.org/10.1080/03075070500392433

Ho, R. (2014). Handbook of univariate and multivariate data analysis with IBM SPSS (2th ed.). Boca Raton, London, New York: Taylor \& Francis Group.

Hu, H. (2007). Effects of self-regulated learning strategy training on learners' achievement, motivation and strategy use in a web- enhanced instructional environment (Unpublished Dissertation). Florida State University, Florida, U.S.

Kabapınar, Y. (2007). İlköğretimde hayat bilgisi ve sosyal bilgiler öğretimi. Ankara: Maya Yayınları.

Kılıç, Z. (2015). Active learning practices on the development of students' life skills in life science course (Unpublished doctoral dissertation). Anadolu University, Turkey.

Kim, E., \& Seo, E. H. (2013). The relationship of flow and self-regulated learning to active procrastination. Social Behaviour and Personality, 41(7), 1099-1114. https://doi.org/10.2224/sbp.2013.41.7.1099

Kimber, C. T. (2009). The effect of training in self-regulated learning on math anxiety and achievement among preservice elementary teachers in a freshman course in mathematics concepts (Unpublished doctoral dissertation). Temple University, U.S.

Kosnin, A. M. (2007). Self-regulated learning and academic achievement in Malaysian undergraduates. International Education Journal. Retrieved from http://files.eric.ed.gov/fulltext/EJ841762.pdf

Kuyumcu, Vardar A. (2011). The effect of self-regulated learning strategies instruction on students' Engilish achievement, self-regulated learning strategy use and attitude (Unpublished doctoral dissertation). Abant Izzet Baysal University, Turkey.

MEB (2009). İlköğretim kurumlar hayat bilgisi dersi ögretim programi. http://ttkb.meb.gov.tr/www/ogretim-programlari/icerik/72 adresinden 05.02.2013 tarihinde elde edilmiştir.

Mega, C., Ronconi, L., \& De Beni, R. (2014). What Makes a Good Student? How Emotions, Self-Regulated Learning, and Motivation Contribute to Academic Achievement. American Psychological Association, 1(106), 121-131. https://doi.org/10.1037/a0033546

Özdemir, M. (1998). Hayat bilgisi oğrenme ve öğretme etkinlikleri. Ankara: Pegem Akademi Yayıncılık.

Pintrich, P. R. (2000). The role of goal orientation in self-regulated learning. In M. Boekaerts, P. R. Pintrich \& M. Zeidner (Eds.), Handbook of self-regulation (pp.451-502). San Diego, San Francisco New York Boston London Sydney Tokyo: Academic Press. https://doi.org/10.1016/B978-012109890-2/50043-3

Quince, B. R. (2013). The effects of self-regulated learning strategy Instruction and structured-diary use on students' self-regulated learning conduct and academic success in online community-college general education courses (Unpublished doctoral dissertation). University of San Francisco, U.S.

Ramdass, D., \& Zimmerman, B. J. (2011). Developing self-regulation skills: The important role of homework. Journal of Advanced Academics, 22(2), 194-218. https://doi.org/10.1177/1932202X1102200202

Sarı, A., \& Akınoğlu, O. (2009). Self-regulated learning: Models and applications. Marmara Universitesi Eğitim Fakültesi Dergisi, 29, 139-15.

Sönmez, V. (2005). Hayat bilgisi ve sosyal bilgiler öğretimi (5. baskı). Ankara: Anı Yayıncılık.

Turan, S. (2009). The relationship between attitudes to problem-based learning, skills and achievement (Unpublished 
doctoral dissertation). Hacettepe University, Turkey.

Turan, S., Demirel, Ö., \& Sayek, İ. (2009). Metacognitive awareness and self-regulated learning skills of medical students in different medical curricula, Medical Teacher, 31. https://doi.org/10.3109/01421590903193521

Winne, P. H. (1996). A metacognitive view of individual differences in self-regulated learning. Learning and Individual Differences, 8(4), 327- 353. https://doi.org/10.1016/S1041-6080(96)90022-9

Winne, P. H., \& Hadwin, A. F. (1998). Studying as self-regulated learning. In D.J. Hacker \& J. Dunlosky (Eds.), Metacognition in educational theory and practice, the educational psychology series. Mahwah, NJ: Erlbaum.

Zimerman, B. J., \& Martinez-Pons, M. (1990). Student differences in self regulated learning: relating grade, sex, and giftedness to self-efficacy and strategy use. Journal of Education Psychology, 1(82), 51-59. https://doi.org/10.1037/0022-0663.82.1.51

Zimmerman, B. J. (1989). A social cognitive view of self-regulated academic learning. Journal of Educational Psychology, 81, 329-339. https://doi.org/10.1037/0022-0663.81.3.329

Zimmerman, B. J. (1990). Self-regulating academic learning and achievement: the emergence of a social cognitive perspective. Educational Psychology Review, 2, 173-201. https://doi.org/10.1007/BF01322178

Zimmerman, B. J. (1998). Developing self-fulfilling cycles of academic regulation: An analysis of exemplar instructional models. In (D.H. Schunk \& B.J. Zimmerman (Eds.), Self-regulated learning from teaching to self-reflective practice (pp. 1-19). New York London: The Guilford Press.

Zimmerman, B. J., \& Kitsantas, A. (2005). The hidden dimension of personal competence: Self-regulated learning and Practice. In A.J. Elliot, \& C.S. Dweck (Eds.), Handbook of competence and motivation (pp.509-526). New York London: The Guilford Press.

Zimmerman, B. J., Bandura, A., \& Martinez-Pons, M. (1992). Self-motivation for academic attainment: The role of self-efficacy beliefs and personal goal setting. American Educational Research Journal, 29, 663-676. https://doi.org/10.3102/00028312029003663

\section{Copyrights}

Copyright for this article is retained by the author(s), with first publication rights granted to the journal.

This is an open-access article distributed under the terms and conditions of the Creative Commons Attribution license which permits unrestricted use, distribution, and reproduction in any medium, provided the original work is properly cited. 